\title{
Efficient adsorption of pharmaceutical drugs from aqueous solution using a mesoporous activated carbon
}

\author{
Tetiana Hubetska ${ }^{a^{*}}$ Natalia Kobylinskab José R. García ${ }^{\mathrm{a}}$ \\ ${ }^{a}$ Department of Organic and Inorganic Chemistry, University of Oviedo-CINN, Oviedo, Spain \\ ${ }^{b}$ Department of Analytical Chemistry, Taras Shevchenko National University of Kyiv, Kyiv, Ukraine \\ *thubetska@gmail.com
}

\begin{abstract}
The removal of widely used pharmaceuticals by new granular mesoporous activated carbon materials prepared via a simple one-step pyrolysis process was studied. The series of mesoporous carbons (MC) were derived from sucrose/polystyrene using two mesoporous matrices: MCM-48 and SBA-15 sieves. Two different activation schemes were used to obtained samples: steam-pyrolysis at $900{ }^{\circ} \mathrm{C}$, and chemical modification (with $\mathrm{HNO}_{3}, \mathrm{H}_{2} \mathrm{O}_{2}$ and their mixture) at $200{ }^{\circ} \mathrm{C}$. The studied conditions of chemical oxidation led to significant structural alterations. Compared to the activated carbon treated by steam at $900{ }^{\circ} \mathrm{C}$, the treatment via chemical oxidation increased the total volume of pores from 1.09 to $2.73 \mathrm{~cm}^{3} \cdot \mathrm{g}^{-1}$. The total adsorption capacity towards tetracycline was found to be proportional to the mesoporous volume and the amount of surface O-containing groups. From the experimental adsorption isotherms, the maximum adsorption capacity was calculated $909.2 \mathrm{mg} \cdot \mathrm{g}^{-1}$ for tetracycline at $\mathrm{pH}=7$. The kinetics of adsorption fits the pseudo-second order model perfectly. The adsorption data treated by both Langmuir and Freundlich models indicates that the adsorption was monomolecular. This research provides insight into the adsorption behavior of antibiotics on non-activated and activated mesoporous carbonous materials and facilitates their application to removal of pharmaceuticals from contaminated aqueous solutions. The potential adsorption mechanism of mesoporous carbons for the adsorption of antibiotics was proposed. The granular mesoporous carbon after oxidation by mixture of $\mathrm{HNO}_{3}$ and $\mathrm{H}_{2} \mathrm{O}_{2}$ with ration 1:1 exhibited much higher adsorptive activity and still showed relatively high adsorption stability even after five cycles, which were potentially suitable for easy separation and high efficiency.
\end{abstract}

Keywords: granular ordered carbon, hydrothermal synthesis, chromatography, conductometric titration, regeneration, tetracycline antibiotics.

\section{Introduction}

One of today's most expanding scientific fields is pharmacy, which continues to grow. The presence of pharmaceutical compounds in the environment and their potential effects constitute the focus of environmental and health organizations worldwide. However, pharmaceutical compounds continue to be released into the environment by medical facilities and private households and via production effluents (Lateefa 2017). Pharmaceuticals as emerging pollutants have become a major concern because of their low biodegradability, high persistence, and ease of bioaccumulation. These compounds include diverse types of pharmaceuticals, such as antibiotics, anti-inflammatory agents, blood-lipid regulators, and steroidal hormones (Ahmed 2018).

Tetracycline (TC) is one of the most widely used antibiotics, its presence often being noted in aquatic farms, foodstuffs (McEvoy 2002), groundwater, surface water, etc. (Duff 2005, Kummerer 2009). A study by Boatman (1998) revealed that more than 2500 tons of TC are used annually for veterinary purposes in Europe alone. Thus, it is vital to adopt measures to remove this compound from the ecosystem (Salvia 2014, Fatta-Kassinos 2011).

Several methods have been applied to treat pharmaceutical pollutants, such as photocatalytic degradation, microextraction, oxidation, biodegradation, chlorination, biofiltration, electrocoagulation, flotation, and electrochemical oxidation (Muthanna 2017). However, these current methods have drawbacks related to high operating and maintenance costs and the formation of byproducts with greater toxicity than the original pollutants. The adsorption method, however, has several advantages, such as ease of operation, low costs, high efficiency, and no risk of the formation of highly toxic byproducts. The adsorbed pollutants are located inside the pores of the adsorbents and do not undergo chemical transformations (Fatta-Kassinos 2011). 
Numerous studies have been carried out to explore efficient adsorbent materials. A variety of adsorbents have recently been developed for the removal of pharmaceutical pollutants: native and modified clays (Andrade 2018, Polubesova 2006), mesoporous silica particles (Churu 2015), activated carbons or graphene oxide, biochar (Ahmed 2015), and others. Among those adsorbents, carbon-based materials have been recommended as better adsorbents for pharmaceutical drug contaminants because of their fascinating properties, which include low density, low cost, non-toxicity for the environment, and excellent adsorption abilities (Álvarez-Torrellas 2015). Adsorption by carbon materials results in efficient removal of a broad spectrum of pollutants, in particular uncharged and non-polar compounds (oil/water distribution constant log $\mathrm{K}_{\mathrm{ow}}>2$ ). This efficiency is attributed to their porous structure, which provides a large surface area for adsorption. Furthermore, their surface chemistry and pore size distribution are critical factors governing the degree of pharmaceuticals removal (Álvarez-Torrellas 2017). The role of surface chemical activation and modification of carbons is known to be essential in their adsorbent behavior in solution, essentially because of the polarity and acidity of the surface chemical groups and their steric role in the accessibility of the micropores (Guedidi 2013). Chemical activation of carbon has been obtained using $\mathrm{ZnCl}_{2}$ and $\mathrm{NaOH}, \mathrm{KOH}$, $\mathrm{K}_{2} \mathrm{CO}_{3}, \mathrm{H}_{3} \mathrm{PO}_{3}$ among other reagents, under relatively mild reaction conditions (e.g. $300-900^{\circ} \mathrm{C}$ ). The surface chemistry of the activated carbons can be modified to treatment by oxigen agent such as $\left(\mathrm{NH}_{4}\right)_{2} \mathrm{~S}_{2} \mathrm{O}_{8}, \mathrm{HNO}_{3}$, $\mathrm{H}_{2} \mathrm{O}_{2}, \mathrm{H}_{2} \mathrm{SO}_{4}$, etc. (Boehm 2002, Moreno-Castilla 1998). It has been found that this chemical oxidation method can produce the maximum possible surface oxygen groups while improving mesoporous specific surface areas and porosities. The competing role between surface chemistry and pore size was also evidenced in the adsorption of organic molecules by carbons (Figueiredo 2010, El-Sayded 2004). The presence of surface N,O-containing functional groups, including carboxyl, carbonyl, phenol, quinone and lactone groups or $\mathrm{H}_{2} \mathrm{O}$ molecules, can play a primary role in selectively removal some of organic pollutants (Husbands 1971, Zhou 2006). The adsorptive performance of activated carbon for antibiotics such as $\beta$ lactam/amoxicillin (Moussavi 2013, Putra 2009), cephalexin (Pouretedal 2014), penicillin (Ania 2011), sulfamethoxazole (Moral-Rodríguez 2016), and tetracycline (Martins 2015) has likewise been studied.

The key innovative ideas of this study are to: (1) build a new strategy for the synthesis of granular mesoporous carbon (MC) based on molecular sieves as the template using sucrose-precursor and selected organic polymers which increase the mechanical and thermal stability and structure of the materials obtained with the precursors; (2) investigate the possibility of using steam-pyrolysis and chemical activation (with $\mathrm{HNO}_{3}, \mathrm{H}_{2} \mathrm{O}_{2}$ and their mixture) to prepare a highly efficient adsorbent for the removal of pharmaceutical pollutants; (3) study various parameters (initial $\mathrm{pH}$, contact time, etc.) influencing the adsorption of pharmaceuticals; (4) determine the kinetic and thermodynamic parameters involved in the adsorption process; and, finally, (5) to understand the adsorption mechanism of pharmaceuticals onto mesoporous carbon. The following antibiotics were used as model analytes: tetracycline (TC), oxytetracycline (OTC), chlortetracycline (CTC), and doxycycline (DC).

\section{Experimental part}

\subsection{Materials}

All the chemicals employed in this study were of analytical grade and were used as received without further purification. Ultra-pure water was obtained from a Milli-Q apparatus.

The standard solutions of the pharmaceutical drugs (tetracycline, oxytetracycline, chlortetracycline, and doxycycline) were purchased from Aldrich. The working solutions of the pharmaceuticals and the initial standards (I.S.) were prepared in methanol $\left(1.0 \mathrm{~g} \cdot \mathrm{mL}^{-1}\right)$ and stored at $4{ }^{\circ} \mathrm{C}$ in a dark place (in a refrigerator).

All other chemicals were obtained from Sigma-Aldrich.

\subsection{Synthesis of mesoporous carbonous samples.}

The MCM-48 and SBA-15 sieves were prepared via hydrothermal synthesis using TEOS as the silica source, as described in (Zhao 1998). Carbonization experiments were performed via two-step impregnation of the molecular sieves with a solution of polystyrene using the incipient wetness method. In a typical experiment, $5 \mathrm{mg}$ silica was mixed with $6.25 \mathrm{~g}$ sucrose $(\geq 99.5 \%(\mathrm{GC})), 0.9 \mathrm{~g}$ concentrated $\mathrm{H}_{2} \mathrm{SO}_{4}(95 \%)$, and $30 \mathrm{~mL}$ $\mathrm{H}_{2} \mathrm{O}$. This mixture was then added to a solution of $1.25 \mathrm{~g}$ polystyrene (average $\mathrm{M}_{\mathrm{w}} \sim 192,000 \mathrm{~g} \cdot \mathrm{mol}^{-1}$ ) in toluene $(10 \mathrm{~mL})$. The resultant mixture was dried for $5 \mathrm{~h}$ at $100^{\circ} \mathrm{C}$. This partially carbonized material was 
blended with a solution consisting of $3.75 \mathrm{~g}$ sucrose, $0.5 \mathrm{~g} \mathrm{H}_{2} \mathrm{SO}_{4}(95 \%)$, and $30 \mathrm{~mL} \mathrm{H}_{2} \mathrm{O}$. The mixture thus obtained was dried again $6 \mathrm{~h}$ at $100{ }^{\circ} \mathrm{C}$. The resultant powder was calcined and carbonized under vacuum in a quartz reactor at $900{ }^{\circ} \mathrm{C}$ for $3 \mathrm{~h}$. The black composite was treated by $1 \mathrm{M} \mathrm{NaOH}$ solution of $70 \%$ ethanol in order to dissolve the silica template. The obtained carbon sample was filtered, washed in ethanol and then distilled water, dried at $100{ }^{\circ} \mathrm{C}$, and then optionally treated in a steam-pyrolysis reactor at $900{ }^{\circ} \mathrm{C}$ in an inert atmosphere (Telbiz 2011). The obtained carbon samples were designated as MC-SBA and MC-MCM. Mesoporous carbon was synthesized using the same method without adding the template (MC).

\subsection{Chemical treatment of surface carbonous samples.}

After removing the template, the carbon materials were treated with various chemical activation agents. Approximately $5 \mathrm{~g}$ of each reference sample were heated in $50 \mathrm{~mL}$ of an activation agent at $65{ }^{\circ} \mathrm{C}$ in an autoclave for 24 hours. The mixture was then filtered, washed with hot distilled water, and dried in an oven at $110{ }^{\circ} \mathrm{C}$ for 24 hours. The dried sample was loaded into a stainless steel reactor and placed inside a graphite furnace. The activation procedure was carried out under purified nitrogen at $400{ }^{\circ} \mathrm{C}$ for $1 \mathrm{~h}$. The following solutions were used as the chemical activation agents: $\mathrm{HNO}_{3}(63 \mathrm{wt} \%), \mathrm{H}_{2} \mathrm{O}_{2}(30$ wt. \%) and their mixture at ratios of $1: 1$ and 1:2. The carbon samples were designated as MC-SBA/MCM(HNO $\left.{ }_{3}\right)$, MCSBA/MCM $\left(\mathrm{H}_{2} \mathrm{O}_{2}\right)$, MC-SBA/MCM $\left(\mathrm{HNO}_{3}+\mathrm{H}_{2} \mathrm{O}_{2}\right)$, and MC-SBA/MCM $\left(\mathrm{HNO}_{3}+2 \mathrm{H}_{2} \mathrm{O}_{2}\right)$, respectively.

Commercial activated carbon (untreated, Fluka (CAS: 7440-44-0)), with a high specific surface area, was used as a benchmark to study adsorption properties toward tetracycline.

\subsection{Characterization methods.}

The morphological and physico-chemical characteristics of the carbon adsorbents were obtained from $\mathrm{ad}$ /desorption isotherms of nitrogen, powder X-ray diffraction (XRD), Fourier transform infrared (FTIR), transmission electron microscope (TEM), and thermal analysis with MS detection. Powder XRD data were obtained at room temperature using a PANalytical X'Pert Pro high resolution diffractometer operating at a Ni-filtered $\mathrm{CuK} \alpha(\lambda=1.5406 \AA)$ radiation. FTIR spectra were recorded from the samples pressed into pellets with $\mathrm{KBr}$ using a Nexus 470 Nicolet spectrometer. Thermal analysis measurements were performed on a Mettler-Toledo TGA/SDTA851 combined with Pfeifer Vacuum Thermostar GSD301T. The particle size and morphology of the samples were determined under a JEOL 2100F TEM operating at $200 \mathrm{kV}$. Nitrogen ad/desorption isotherms were recorded at $77 \mathrm{~K}$ using a Micromeritics ASAP 2020 instrument. Before the measurement, the samples were outgassed at $120^{\circ} \mathrm{C}$ (12 hours).

The total amount of acidic-oxygenated groups on the obtained activated carbon surface was determined by the simultaneous conductometric-potentiometric titration method using a standard $\mathrm{NaOH}$ solution (0.01-0.05 mol$\left.\cdot \mathrm{L}^{-1}\right)$ after reaching equilibrium. The carbon sample $(0.2 \mathrm{~g})$ was added to water $(20 \mathrm{~mL})$ and incubated for $24 \mathrm{~h}$. The conductivity and $\mathrm{pH}$ data of selected suspensions were obtained with a Mettler Toledo ${ }^{\mathrm{TM}}$ EL3 conductometer and an I160M ionomer, respectively.

\subsection{Adsorption experiments and sample preparation.}

Batch sorption experiments were carried out in a series of $50 \mathrm{~mL}$ glasses containing $25 \mathrm{~mL}$ of a $60 \mathrm{mg} \cdot \mathrm{L}^{-1}$ solution of tetracycline. Predetermined amounts of adsorbents $(0.1 \mathrm{~g})$ were added to the glass. All the experiments were performed in the dark in a thermostatically controlled shaker, maintained at $200 \mathrm{rpm}$ and a pre-set temperature of $25^{\circ} \mathrm{C}$. Based on the results from preliminary kinetic studies, a stirring time of $2 \mathrm{~h}$ was selected as the equilibrium time for all the sorbents. On completion of the sorption experiments with activated carbon, samples were filtered through $0.45 \mu \mathrm{m}$ membrane filters to separate the activated carbon particles from the aqueous phase. The tetracycline concentration in the filtrate was measured by high performance liquid chromatography (HPLC).

The adsorption capacity of adsorbents was calculated as the difference between the amount of analyte initially added to the system and the amount remaining in the solution after equilibration using the following equation:

$$
\mathrm{q}_{\mathrm{e}}=\frac{\left(\mathrm{C}_{\mathrm{i}}-\mathrm{C}_{\mathrm{e}}\right) \cdot \mathrm{V}}{\mathrm{m}}
$$

where, $\mathrm{q}_{\mathrm{e}}$ is the amount of pharmaceuticals adsorbed per mass unit of adsorbent at equilibrium $\left(\mathrm{mg}^{-1} \mathrm{~g}^{-1}\right) ; \mathrm{C}_{\mathrm{i}}$ and $\mathrm{C}_{\mathrm{e}}$ are the initial and equilibrium concentrations of the pharmaceuticals $\left(\mathrm{mg} \cdot \mathrm{L}^{-1}\right) ; M_{r}$ is the molecular 
weight of the pharmaceuticals $\left(\mathrm{g} \cdot \mathrm{mol}^{-1}\right) ; V$ is the volume of the solution $(\mathrm{L})$; and $m$ is the mass of the adsorbent (g).

\subsection{Determination of antibiotics}

An HPLC system (Agilent 1260) equipped with a Discovery C18 column (150 mm x $4.6 \mathrm{~mm}$ I.D., $5 \mu \mathrm{m})$ and a UV-Vis detector was used to measure the pharmaceutical concentrations at a detection wavelength of 230$290 \mathrm{~nm}$. The mobile phase used for elution was a mixture of $25 \mathrm{mM} \mathrm{KH}_{2} \mathrm{PO}_{4}$ at $\mathrm{pH}=3.0(40 \%)$ and acetonitrile $(60 \%)$, delivered at $1 \mathrm{~mL} \cdot \mathrm{min}^{-1}$ through the column. A sample injection volume of $100 \mu \mathrm{L}$ was used, and three measures of each individual solution were acquired. The column temperature was maintained at $30{ }^{\circ} \mathrm{C}$. For quantification purpose, calibration curves were prepared within the range of experimental concentrations of the respective standard sample employed.

To ascertain the linearity, the stock solution of the standard $\left(1 \mathrm{mg} \cdot \mathrm{mL}^{-1}\right)$ was diluted to five different concentrations $\left(5,10,20,30,50 \mu \mathrm{g} \cdot \mathrm{mL}^{-1}\right)$, which were individually fed in triplicate into the HPLC system. The calibration curve was subsequently obtained by plotting the peak area versus the concentration for each sample, where the square of the correlation coefficient $R^{2}>0.99$ is indicative of the measure of linearity.

\section{Results and Discussion}

\subsection{Synthesis and characterization of mesoporous carbonous materials}

The synthesis of mesoporous activated carbon applying periodically ordered mesoporous silica as a template has been widely used (Kruk 2000). Molecular sieves such as SBA-15 and MCM-48 was used for preparation mesoporous carbon replicas with large surface areas and a network with a high degree of hexagonal order (Mbileni 2006, Fuertes 2003). For this approach, thermal reduction of the organic precursor via the filling of molecular sieve pores with organic polysaccharide (sucrose) and polymer (polystyrene) followed by annealing in an inert atmosphere was applied to prepare granular carbon replicas of the mesoporous framework (Fig.1).

Fig. 1. Schematic representation of the preparation of granular mesoporous carbons.

The oxidation level of the carbon samples was varied by changing the pyrolysis conditions and the amount of $\mathrm{H}_{2} \mathrm{O}_{2}, \mathrm{HNO}_{3}$, and their mixture as the chemical activation agents (Miyata 2006, Hong 2007). Mesostructured carbonous samples were characterized before and after chemical activation.

XRD was used to estimate the mesoporous ordered arrangement. The small angle XRD patterns (Fig. 2a) of as-synthesized MC-MCM and MC-SBA samples display reflections, indicating that the mesoporous carbon has completely duplicated the long-range order of the SBA-15 and MCM-48 templates. Moreover, the wide angle XRD patterns of the obtained carbon material exhibit peaks at $2 \theta\left(^{\circ}\right)=23$ and 45 which can respectively be ascribed to the (002) and (004) planes and associated with the graphitic pore walls (Xia 2004), indicating that the carbon framework was ordered (Online Resource (Fig. S1)).

Fig. 2. Small angle XRD patterns of the initial (a) and activated (b) mesoporous carbonous materials.

As expected, activation of the sucrose/polystyrene-derived carbonous materials via $\mathrm{H}_{2} \mathrm{O}_{2}$ or $\mathrm{HNO}_{3}$ treatment at $200{ }^{\circ} \mathrm{C}$ did not change the order of the carbon network. Chemical activation of the carbonous samples by the $\mathrm{HNO}_{3}+\mathrm{H}_{2} \mathrm{O}_{2}$ mixture yielded the material with the most well-developed ordered mesoporous network (Fig. 2b).

To gain further information on suitable calcination temperatures for carbonizing the samples, thermogravimetric analyses (TGA) of the aged precursor mixture were performed in $\mathrm{N}_{2}$ gas flows (Fig. 3a). Decomposition of the carbon samples prepared with the sucrose/polystyrene precursor starts at $200{ }^{\circ} \mathrm{C}$ and continues until $600{ }^{\circ} \mathrm{C}$. The results point toward the relatively high thermal stability of the MC samples. The ordered arrangements of materials were preserved without collapse after calcination at $550{ }^{\circ} \mathrm{C}$, thus demonstrating good thermal stability. 
Fig. 3. Thermal analysis of the original MC-SBA (a) and chemically activated MC-SBA $\left(\mathrm{H}_{2} \mathrm{O}_{2}+\mathrm{HNO}_{3}\right)$ (b) samples measured in flowing nitrogen atmosphere.

From the DTA curves in Fig. 3, an obvious weight loss accompanying broad exothermic peaks between ca. 200 and $600{ }^{\circ} \mathrm{C}$, attributed to the combustion of carbon, is observed in the TG data in the surrounding $\mathrm{N}_{2}$. The gradual weight loss with a small, broad exothermic shoulder visible between 100 and $900{ }^{\circ} \mathrm{C}$ should result from the residual physical adsorption of $\mathrm{H}_{2} \mathrm{O}$ molecules and continuous removal of carbon.

The critical step for designing high performance carbon absorbers with an ordered mesoporous structure is a fully removed template (silica matrix) after treatment with $\mathrm{NaOH}$. Fig. 3a shows the TG curves of the original MC-SBA and MC with the template obtained under a nitrogen atmosphere. The original MCSBA decomposes completely above $600{ }^{\circ} \mathrm{C}$, the remaining weight being $32.3 \mathrm{wt}$. $\%$ in the tested temperature range. Therefore, the weight percent of the $\mathrm{SiO}_{2}$ with respect to carbon can be calculated as $14.5 \mathrm{wt}$. \% by comparing and analyzing the TG curves. The activated MC-SBA $\left(\mathrm{H}_{2} \mathrm{O}_{2}+\mathrm{HNO}_{3}\right)$ is degraded between 250 and $800{ }^{\circ} \mathrm{C}$, subsequently leaving the thermally stable mesoporous carbon. This temperature range is clearly higher than that for the degradation of the original MC-SBA, indicating the higher thermal stability of the activated mesoporous samples on the carbon surfaces. The TG curve of MC-SBA $\left(\mathrm{H}_{2} \mathrm{O}_{2}+\mathrm{HNO}_{3}\right)$ reveals a weight loss of $85.5 \mathrm{wt}$. \%. This effect signifies that full thermal decomposition of carbon occurred and that the $\mathrm{SiO}_{2}$ matrix was removed from the carbon samples.

The pore morphology and ordered structure of these carbon samples were investigated by TEM microscopy. Significant differences are observed in the porous structure of the three carbon samples (Fig. 4). The carbon solids synthesized without a template exhibited a smooth surface and some wrinkles which did not present porous structures. The ordered mesopores of MC-MCM and MC-SBA are clearly observed in Fig. 4(b,c), being in good agreement with the small angle XRD patterns. The (002) lattice fringes of the graphitic structure and mesoporous carbon are clearly observed in the TEM image (see Fig. 4c).

Fig. 4. TEM images of the synthesized carbon samples obtained without a silica-template (a), MCM-48 (b) and SBA-15 (c) based products.

The $\mathrm{N}_{2}$ ad/desorption isotherms of the SBA- and MCM-based non-activated carbon show in Figure $5 \mathrm{a}$. The slopes of the isotherms become sharply steeper as the relative pressure increases and tend to nonplateau at a high relative pressure. These isotherms are of type IV (Thommes 2015) with a low hysteresis loop characteristic of mesoporous materials. The isotherms of carbon activated under different conditions had similar tendencies (Fig. 5b). After activation, the adsorption of nitrogen increases continually until the relative pressure becomes equal to 1 . The presence of the hysteresis loop of type IV at a relative pressure $>0.4$ proves formation of slit-like pores associated with capillary condensation in well-developed mesoporous materials (Bottani 2008).

Fig. 5. $\mathrm{N}_{2}$ ad/desorption isotherms and pore size distributions of the synthesized non-activated (a) and chemically activated (b) mesoporous carbon samples.

The evolution of the specific surface area and pores from micro- to mesopores due to the influence of different factors such as type of template, pyrolysis, and chemical activation conditions was evaluated (Table 1). The BET specific surface area of the ordered carbon materials after chemical activation is higher than that of the corresponding carbon samples treated only via pyrolysis. The specific surface areas of the initial molecular sieves are respectively 1420 and $1093 \mathrm{~m}^{2} \cdot \mathrm{g}^{-1}$ versus 1720 and $1800 \mathrm{~m}^{2} \mathrm{~g}^{-1}$ for the SBA-15 and MCM-48 based carbonous samples.

Table 1. Textural characteristics of the initial silica matrices and derivative carbonous materials

$\begin{array}{lll}\text { Sample } & \mathrm{S}_{\mathrm{BET}}, & \text { NLDFT method }\end{array}$




\begin{tabular}{|c|c|c|c|c|c|c|c|c|}
\hline & $\mathrm{m}^{2} / \mathrm{g}$ & $\begin{array}{c}V_{\text {tot }}, \\
\mathrm{cm}^{3} / \mathrm{g}\end{array}$ & $\begin{array}{l}\mathrm{V}_{\text {mic }}, \\
\mathrm{cm}^{3} / \mathrm{g}\end{array}$ & $\begin{array}{r}V_{\text {mes }} \\
\mathrm{cm}^{3} / \mathrm{g}\end{array}$ & $\begin{array}{l}V_{\text {mac, }} \\
\mathrm{cm}^{3} / \mathrm{g}\end{array}$ & $\mathrm{D}, \mathrm{nm}$ & $\begin{array}{c}\mathrm{V}_{\text {tot }} \\
\mathrm{cm}^{3} / \mathrm{g}\end{array}$ & $\mathrm{D}, \mathrm{nm}$ \\
\hline \multicolumn{9}{|c|}{ silica templates } \\
\hline MCM-48 & 1420 & 1.35 & 0.10 & 1.09 & 0.16 & 3.15 & - & - \\
\hline SBA-15 & 1093 & 1.14 & 0.03 & 1.03 & 0.08 & 3.80 & - & - \\
\hline \multicolumn{9}{|c|}{ steam-pyrolysis at $900^{\circ} \mathrm{C}$} \\
\hline MC(without a template) & 750 & 0.70 & 0.41 & 0.20 & 0.09 & 0.52 & - & - \\
\hline MC-MCM & 1800 & 1.14 & 0.10 & 0.96 & 0.08 & 3.12 & 1.45 & 3.20 \\
\hline MC-SBA & 1720 & 1.69 & 0.09 & 1.56 & 0.04 & 4.50 & 1.10 & 4.49 \\
\hline \multicolumn{9}{|c|}{ chemical activation } \\
\hline $\mathrm{MC}-\mathrm{SBA}\left(\mathrm{HNO}_{3}\right)$ & 1760 & 1.34 & 0.11 & 1.18 & 0.05 & 4.00 & 1.35 & 4.08 \\
\hline $\mathrm{MC}-\mathrm{SBA}\left(\mathrm{H}_{2} \mathrm{O}_{2}\right)$ & 2020 & 2.38 & 0.10 & 2.19 & 0.09 & 4.84 & 2.38 & 4.82 \\
\hline $\mathrm{MC}-\mathrm{SBA}\left(\mathrm{HNO}_{3}+\mathrm{H}_{2} \mathrm{O}_{2}\right)$ & 2340 & 2.51 & 0.09 & 2.35 & 0.07 & 6.61 & 2.53 & 6.59 \\
\hline $\mathrm{MC}-\mathrm{SBA}\left(\mathrm{HNO}_{3}+2 \mathrm{H}_{2} \mathrm{O}_{2}\right)$ & 2180 & 2.73 & 0.10 & 2.47 & 0.16 & 5.81 & 2.18 & 5.50 \\
\hline $\mathrm{MC}-\mathrm{MCM}\left(\mathrm{HNO}_{3}+\mathrm{H}_{2} \mathrm{O}_{2}\right)$ & 1890 & 2.18 & 0.10 & 2.04 & 0.04 & 5.51 & 2.85 & 5.00 \\
\hline
\end{tabular}

Notes. $\mathrm{S}_{\mathrm{BET}}$ - Brunauer-Emmet-Teller specific surface area, $\mathrm{m}^{2} / \mathrm{g} ; \mathrm{V}_{\text {tot }}, \mathrm{V}_{\text {mic }}, \mathrm{V}_{\text {mes }}, \mathrm{V}_{\mathrm{mac}}$ - total, micro-, meso- macroporous volume, respectively, $\mathrm{m}^{3} / \mathrm{g} ; \mathrm{D}$ - diameter of pores, $\mathrm{nm}$.

These data demonstrate that the surface area increases after chemical activation by individual chemical agents and even more after exposure to their mixture, respectively (Table 1). Following the individual $\mathrm{H}_{2} \mathrm{O}_{2}$ treatment, the surface area increased sharply to $2020 \mathrm{~m}^{2} \cdot \mathrm{g}^{-1}$. Activation with mixture $\mathrm{H}_{2} \mathrm{O}_{2}+$ $\mathrm{HNO}_{3}$ agents produced a material with the highest specific surface area $\left(2340 \mathrm{~m}^{2} \cdot \mathrm{g}^{-1}\right.$ for the MC$\mathrm{SBA}\left(\mathrm{HNO}_{3}+\mathrm{H}_{2} \mathrm{O}_{2}\right)$ sample) and high pore volumes (Table 1). However, when compared with the $\mathrm{HNO}_{3}{ }^{-}$ activated carbons, the MC-SBA $\left(\mathrm{HNO}_{3}\right)$ sample presents the lowest sorption characteristics. The $\mathrm{H}_{2} \mathrm{O}_{2}$ activation produced wider pores than steam pyrolysis and $\mathrm{HNO}_{3}$ activation. The increased amount of $\mathrm{H}_{2} \mathrm{O}_{2}$ in the activation mixture produced porosity, although the material's mechanical stability also decreased. This shows that the hydrogen peroxide molecules played an important role in the development of porosity. This effect may be the result of optimal heating during the carbonization process and the subsequent formation of new slit pores in the carbon granules (Fig. 6). As the activation process also comprises a partial oxidation reaction in addition to pyrolysis and acid treatment, $\mathrm{O}$ - and $\mathrm{N}$-containing functional groups are inevitably formed on the surface of the carbon.

Fig. 6. Schematic illustration of the chemical activation of mesoporous SBA-based carbon samples.

The pore volume and diameter of the activated carbon (Fig. 5) were calculated by the nonlocal density functional theory (NLDFT) and Barrett-Joyner-Halenda (BJH) methods, and are shown in Table 1. In general, the method of $\mathrm{BJH}$ was originally designed for relatively wide-pore adsorbents such as mesoporous materials correspond to the type-IV isotherm with a wide hysteresis loop (Barrett 1951). As can be observed, MC-MCM and MC-SBA showed the narrowest pore size distributions, indicating that the majority of the pores had a diameter near 1.1-1.7 nm, while MC (without template) showed pore sizes smaller than $1 \mathrm{~nm}$. Thus, the pore size distributions shown in Figure 5a support the results given in Table 1, confirming that the MC obtained had well-developed porosity. The Figure 5b and Table 1 results are shown that the porosities properties MC derived increase after chemical activation of the carbonous samples. Growth of porosity is thus demonstrated. $\mathrm{MC}-\mathrm{SBA}\left(\mathrm{HNO}_{3}\right)$ showed a low development of mesoporosity in comparison to MAC$\mathrm{SBA}\left(\mathrm{H}_{2} \mathrm{O}_{2}\right)$, probably because the amount of $\mathrm{HNO}_{3}$ was not sufficient to react with all carbon matrix, while their mixture of 1:1 (MC-SBA $\left(\mathrm{HNO}_{3}+\mathrm{H}_{2} \mathrm{O}_{2}\right)$ and $\left.\mathrm{MC}-\mathrm{MCM}\left(\mathrm{HNO}_{3}+\mathrm{H}_{2} \mathrm{O}_{2}\right)\right)$ and 1:2 (MC$\left.\mathrm{SBA}\left(\mathrm{HNO}_{3}+2 \mathrm{H}_{2} \mathrm{O}_{2}\right)\right)$ produced significant mesoporosity. According to these results, the experimental parameters afforded $\mathrm{MC}$ with high values of total pore volume $\left(\mathrm{V}_{\text {tot }}\right)$ and mesoporous volume $\left(\mathrm{V}_{\text {meso }}\right)$ decreased with the mixture of activation agents with ratio 1:2. The greater surface area and larger mesopores were obtained via chemical activation by the mixture of $\mathrm{HNO}_{3}$ and $\mathrm{H}_{2} \mathrm{O}_{2}$ agents with ratio $1: 1$. The developed porosity in obtained MC is directly related to the adsorption performance of adsorbents. 
Fig. 7. FTIR spectra of the obtained mesoporous carbon samples.

The surface functionalities of the synthesized carbonous materials before and after the activation treatment were investigated using FTIR spectroscopy (Fig. 7). The spectra consist of several small overlapping peaks in the regions of 550-890, 1070-1200, 1350-1600 and 3400-3600 $\mathrm{cm}^{-1}$. These types of IR spectra are characteristic of carbon samples (Jia 2000). The series of characteristic functional groups could be easily spotted: (1) $v_{\mathrm{s}}(\mathrm{OH})$ in hydroxyl and carboxyl $\left(\approx 3430-3400 \mathrm{~cm}^{-1}\right)$ groups; $(2)-\mathrm{C}=\mathrm{O}$ in carboxylic acid $\left(1720 \mathrm{~cm}^{-1}\right)$ and carbonyl moieties $\left(1600 \mathrm{~cm}^{-1}\right)$; (3) $\mathrm{sp}^{2} \mathrm{C}=\mathrm{C}$ of aromatic rings $\left(1490 \mathrm{~cm}^{-1}\right)$; and (4) benzene ring structure $\left(890 \mathrm{~cm}^{-1}\right)$. The bands at $2850-2930 \mathrm{~cm}^{-1}$ and $3011 \mathrm{~cm}^{-1}$ are attributed to $v(\mathrm{C}-$ $\mathrm{H})$ stretching vibration of the aliphatic and aromatic structures, respectively. A band at $1600 \mathrm{~cm}^{-1}$ is generally ascribed to $\mathrm{C}=\mathrm{O}$ stretching vibration in the carbonyl group.

There is an obvious difference in spectra of the obtained samples after chemical activation with respect to the sample which was not chemically activated (Fig. 7). The surface activation of the carbon samples with nitric acid and $\mathrm{H}_{2} \mathrm{O}_{2}$ increased the intensity and number of stretching vibrations in the IR spectra. The strong band which appeared at $1600 \mathrm{~cm}^{-1}$ following the chemical treatment could be assigned to $\mathrm{C}=\mathrm{O}$ stretching in the carboxylate, ketone, lactone, and aldehyde groups as the result of acidic treatment and conjugated with $\mathrm{C}=\mathrm{C}$ stretching vibration in the aromatic rings of the carbon structure. The strong bands at 1010 and $1120 \mathrm{~cm}^{-1}$ that appeared following the chemical treatment can be attributed to $v_{\mathrm{s}}(\mathrm{C}-\mathrm{O}-\mathrm{C})$ of the ester groups conjugated with $\mathrm{C}=\mathrm{C}$. Also note the increase in the intensity of the peaks corresponding to various types of $\mathrm{O}$-containing groups including $\mathrm{C}=\mathrm{O}$ (carboxylic group), $\mathrm{C}-\mathrm{OH}$ (hydroxyl group), and $\mathrm{C}-\mathrm{O}$ (phenol group) on the surface of the carbon samples following activation. The presence of the band below $794 \mathrm{~cm}^{-1}$ is ascribed to out-of-plane C-H bending vibrations of aromatic rings. The band at $800-805 \mathrm{~cm}^{-1}$ is associated with the stretching vibration of Si-C, most likely due to the formation of a small amount of carbide in the carbonization step (Colombo 1997). The majority of functional groups are hydrophilic in nature, which is beneficial for dispersion and adsorption of the chemically activated carbonous material in aqueous systems.

Fig. 8. XPS survey spectra for the initial mesoporous carbon (MC-SBA) (a, b) and the corresponding activated material (MC-SBA $\left.\left(\mathrm{HNO}_{3}+\mathrm{H}_{2} \mathrm{O}_{2}\right)\right)(\mathrm{c}, \mathrm{d})$. Deconvolution of the XPS spectra for C $1 \mathrm{~s}(\mathrm{a}, \mathrm{c})$ and O $1 \mathrm{~s}$ (b, d), respectively.

The surface element composition was studied by X-ray photoelectron spectroscopy (XPS) (Fig. 8). Overview spectra in the $0-800 \mathrm{eV}$ range were recorded; the major elements identified were carbon and oxygen. Therefore, fitting of the $\mathrm{C} 1 \mathrm{~s}$ and $\mathrm{O}$ 1s peaks was performed using two main components (each being a mixture of a Gaussian and a Lorentzian) and by approximating the contribution of the background via Shirley's method. The C 1s spectrum for mesoporous carbon presented in Figure 8a can be deconvoluted into four major peaks at 284.3, 285.3, 286.3 and $289.27 \mathrm{eV}$. The peak at $284.3 \mathrm{eV}$ corresponds to C-C bonds of $\mathrm{sp}^{3}$-hybridized carbon atoms. The carbon atoms bonded to hydroxyl groups $(\mathrm{C}-\mathrm{OH})$ are represented by the peak at $286.3 \mathrm{eV}$. The small peak at $289.27 \mathrm{eV}$ can be assigned to $\pi-\pi^{*}$ electronic transitions. The peaks with a binding energy of 284.3 and $285.3 \mathrm{eV}$ may indicate the presence of various types of graphitic structures in the material. The deconvoluted XPS spectra (Fig. 8d) for $\mathrm{O} 1 \mathrm{~s}$ of the non-activated carbonous samples display two types of contributions for oxygen species. One is the oxygen species corresponding to $\mathrm{C}-\mathrm{OH}$ groups $(532.10 \mathrm{eV})$, while the other indicates the presence of $\mathrm{C}-\mathrm{O}-\mathrm{C}$ species on the surfaces of the mesoporous samples $(533.5 \mathrm{eV})$.

According to the $\mathrm{C} 1 \mathrm{~s}$ and $\mathrm{O}$ 1s XPS spectra (Fig. 8(c,d)), after contact with the chemical activating agents the mesoporous carbon samples change the chemical composition and surface concentration distribution of the $\mathrm{O}$-containing groups. Note that the contribution from the peak at $285 \mathrm{eV}$ in the $\mathrm{C}$ spectrum is significant, indicating an increase in the number of $\mathrm{C}=\mathrm{C}$ bonds. The content of phenolic (hydroxyl) groups also increases and the numeric ratio of $\mathrm{C}-\mathrm{O}-\mathrm{C}$ to $\mathrm{C}-\mathrm{OH}$ groups likewise changes from approximately $2: 1$ to 1:1. In the $\mathrm{O} 1 \mathrm{~s}$ spectrum, a peak appears at $531.0 \mathrm{eV}$ which refers to carbonyl $(\mathrm{C}=\mathrm{O})$ or quinone groups. A broad peak at $539.0 \mathrm{eV}(\approx 59 \%)$ indicates the presence of adsorbed water; this means that the resulting materials after activation are more hydrophilic than the initial ones. A slight increase in oxygen content with a significant increase in the relative surface concentration of the $\mathrm{C}-\mathrm{C}$ bonds demonstrates that the terminal groups are predominantly oxidized during oxidation of the carbon samples. 
To clarify this situation, conductometric-potentiometric titration, which has been widely used to determine the amounts of acidic and basic surface groups in functional materials (Zaitsev 2018), was employed to quantify the amounts of specific carboxyl and phenolic groups in the carbonous materials. The titration curves are shown in Online Resource (Fig. S2). Different numbers of end points were observed in various materials. For instance, the titration curve of the MC-SBA $\left(\mathrm{HNO}_{3}\right), \mathrm{MC}-\mathrm{SBA}\left(\mathrm{H}_{2} \mathrm{O}_{2}\right)$, and MC$\mathrm{SBA}\left(\mathrm{HNO}_{3}+\mathrm{H}_{2} \mathrm{O}_{2}\right)$ samples exhibited two end points, which divided the curve into three regions: neutralization of carboxylic acidic groups, neutralization of weak acidic phenolic groups, and excess strong base (Online Resource (Fig. S2), from left to right). The amounts of the specific functional groups on the materials were calculated from the amounts of $\mathrm{NaOH}$ titrated in each stage and are summarized in Table 2.

Table 2. The content of acid groups on the surface of the obtained mesoporous carbon samples.

\begin{tabular}{lccc}
\hline \multirow{2}{*}{ Sample } & \multicolumn{2}{c}{ Acidic groups $(\mathrm{mmol} / \mathrm{g})$} & \multirow{2}{*}{ Total Acidic group $(\mathrm{mmol} / \mathrm{g})$} \\
\cline { 2 - 3 } & Carboxylic & Phenolic & \\
\hline MCM-48 & - & 0.80 & 0.80 \\
SBA-15 & - & 0.75 & 0.75 \\
MC-MCM & 0.03 & 1.05 & 1.08 \\
MC-SBA & 0.04 & 0.75 & 0.79 \\
MC-SBA $\left(\mathrm{HNO}_{3}\right)$ & 0.20 & 0.61 & 0.81 \\
MC-SBA $\left(\mathrm{H}_{2} \mathrm{O}_{2}\right)$ & 0.12 & 1.60 & 1.72 \\
MC-SBA $\left(\mathrm{HNO}_{3}+\mathrm{H}_{2} \mathrm{O}_{2}\right)$ & 1.03 & 2.25 & 3.28 \\
MC-SBA $\left(\mathrm{HNO}_{3}+\mathrm{H}_{2} \mathrm{O}_{2}\right)$ & 0.60 & 1.30 & 1.90 \\
MC-MCM $\left(\mathrm{HNO}_{3}+\mathrm{H}_{2} \mathrm{O}_{2}\right)$ & 0.38 & 1.42 & 1.80 \\
\hline
\end{tabular}

The chemical characteristics of the pristine and chemically activated carbonous samples listed in Table 2 indicate that there are significant differences in the surface concentrations of the total acidic functional groups. In particular, the concentration of carboxyl is higher after activation, which is consistent with the XPS analysis (Fig. 8). Interestingly, there are primary carboxyl groups were determined in the pristine MC-SBA and MC-MCM samples after stream pyrolysis, while more carboxyl groups were observed in solids after chemical activation. This could be attributed to the fact that the primary $\mathrm{OH}$-groups reacting with $\mathrm{HNO}_{3}$ are converted into stable carboxylic groups and other O-containing groups (Fig. 1).

\subsection{Adsorption study of the mesoporous carbon samples}

Adsorption kinetics and isotherm characteristics of the pharmaceuticals on different adsorbents were studied in detail. Furthermore, the solution chemistry of adsorbates vs pH and the regeneration of adsorbents were investigated. In particular, the mechanism of adsorption of tetracycline (TC) onto several of the obtained mesoporous carbons was studied in these respects.

Effect of $\boldsymbol{p H}$. The $\mathrm{pH}$ value plays a key role in the affinity to contaminants, as it affects both the electric charge of their species and the charge density on the surface of the adsorbent (Ting 2017). TC adsorption isotherms for different carbonous samples are summarized in Figure 9.

Fig. 9. Effect of $\mathrm{pH}$ on adsorption of $\mathrm{TC}$ by various carbon samples.

Tetracycline is an amphoteric molecule with multiple ionizable functional groups. It can undergo protonation-deprotonation reactions and present different species depending on the solution $\mathrm{pH}: \mathrm{H}_{3} \mathrm{TC}^{+}(\mathrm{pH}$ $<3.3$ ), neutral or zwitterion species $\left(\mathrm{H}_{2} \mathrm{TC}^{0}, 3.3<\mathrm{pH}<7.68\right)$, or ions with one negative $\left(\mathrm{HTC}^{-}, 7.68<\mathrm{pH}<\right.$ 9.68) or two negative charges $\left(\mathrm{TC}^{2-}, \mathrm{pH}>\right.$ 9.68) (Zhao 2014). It can be seen from Figure 9 that the adsorption of TC on the various carbon samples is $\mathrm{pH}$ dependent. All of the studied carbon materials have the highest affinity to TC under neutral $\mathrm{pH}$. This result may be attributed to the molecular structure of tetracycline and the functional groups present on the surface of the mesoporous carbon (Martins 2015): at the studied $\mathrm{pH}$, the carbon samples mainly have a positively charged surface generated by protonation of the hydroxyl and carboxyl groups in weak acidic medium, as well as negative acidic groups, and TC is in the zwitterionic form. Hence, the TC adsorption mechanism under these conditions can become a contribution 
from complexation between the zwitterionic TC molecules and the respective ionic/polar sites on the adsorbent surface (e.g., H-bonding). In the H-bonding formation, the functional groups in the TC molecule may act as $\mathrm{H}$-acceptors, interacting with the $\mathrm{O}$-containing groups such as $\mathrm{C}=\mathrm{O},-\mathrm{COOH}$ on the surface of the carbon samples. Additionally, the strong interactions of tetracycline directly with the carbon surface cannot be ignored.

Tetracycline adsorption kinetics. The adsorption of TC on non-activated and activated carbon samples is initially rapid $(\approx 15 \mathrm{~min})$ subsequently increasing slowly until the plateau of adsorption equilibrium is reached (Fig. 10). The initial rapid adsorption of TC (within the first $5 \mathrm{~min}$ ) was enhanced after chemical activation of the obtained samples. This finding could be related to the growing amount of vacant active sites on the surface (Chen 2010) which are available for adsorption of TC and is consistent with the previous results of the surface characteristics. The carbonous materials have acidic groups formed in the process of chemical activation by ring opening of the heterocycles. The presence of carboxyl and phenolic groups provides the increased adsorption capacity of the activated carbon. Acidification of the surface gives the activated carbon a higher ion exchange capacity and its amphoteric character as a result of the introduction of various functional groups on its surface (da Costa Lopes 2015). A further aspect to be considered in adsorption is the accessibility of the adsorbate to the activated carbon surface, which is determined by the adsorbate molecule size and the carbon pore dimensions. Thus, the higher adsorption capacity of the activated samples is partly due to their larger mean size of the mesopores and their volume (Table 1), giving TC greater access to their pores and presenting a larger surface fraction that is effective in adsorption compared to the non-activated sample.

Fig. 10. Kinetics of adsorption of TC by the non-activated and activated carbon samples.

Table 3. Kinetic parameters of the adsorption of TC onto different adsorbents at $\mathrm{pH}=7.0-7.2$.

\begin{tabular}{|c|c|c|c|c|c|c|c|}
\hline \multirow{3}{*}{ Sample } & \multicolumn{6}{|c|}{ Calculated data } & \multirow{3}{*}{$\begin{array}{c}\begin{array}{c}\text { Experimental } \\
\text { data }\end{array} \\
\mathrm{q}_{\mathrm{e}}, \mathrm{mg} \cdot \mathrm{g}^{-1}\end{array}$} \\
\hline & \multicolumn{3}{|c|}{ Pseudo-first-order equation } & \multicolumn{3}{|c|}{ Pseudo-second-order equation } & \\
\hline & $\begin{array}{c}\mathrm{q}_{\mathrm{e}} \\
\mathrm{mg} \cdot \mathrm{g}^{-1}\end{array}$ & $\begin{array}{c}\mathrm{K}_{1}, \\
\mathrm{~min}^{-1}\end{array}$ & $\mathrm{R}^{2}$ & $\begin{array}{c}\mathrm{q}_{\mathrm{e}} \\
\mathrm{mg} \cdot \mathrm{g}^{-1}\end{array}$ & $\begin{array}{c}\mathrm{K}_{2}, \\
\mathrm{~g} \cdot \mathrm{mg}^{-1} \cdot \mathrm{min}^{-1}\end{array}$ & $\mathrm{R}^{2}$ & \\
\hline$M C-S B A$ & 166.30 & 0.1675 & 0.9660 & 204.08 & 0.002 & 0.9738 & 189.8 \\
\hline$M C-M C M\left(\mathrm{HNO}_{3}+\mathrm{H}_{2} \mathrm{O}_{2}\right)$ & 276.19 & 0.2326 & 0.9852 & 344.83 & 0.002 & 0.9909 & 327.7 \\
\hline$M C-S B A\left(\mathrm{HNO}_{3}+\mathrm{H}_{2} \mathrm{O}_{2}\right)$ & 228.63 & 0.2527 & 0.9236 & 357.14 & 0.011 & 0.9994 & 345.2 \\
\hline
\end{tabular}

The adsorption kinetics data for TC adsorption by different adsorbents were fitted to pseudo-firstorder and pseudo-second-order equations (Lagergren 1898, Ho 1999). From the behavior of the initial part of the kinetics curve and its shape after linearization, conclusions were drawn regarding the mechanism of the adsorption process (Online Resource (Fig. S3)). Experimental $\mathrm{q}_{\mathrm{e}}$ were calculated using Equation (1).

The applicability of the kinetic model is evaluated by comparing: i) how close $\mathrm{R}^{2}$ approaches 1 , and ii) the experimental and calculated $\mathrm{q}_{\mathrm{e}}$ values (Table 3 ). The $\mathrm{R}^{2}$ values of the pseudo-second-order kinetic model are higher than those of the pseudo-first-order kinetic model, while the differences between the $\mathrm{q}_{\mathrm{e}}$ values are much lower for the pseudo-second-order kinetics with respect to the pseudo-first-order kinetics. Therefore, the pseudo-second-order kinetics model is more appropriate to describe the adsorption behavior of TC onto the carbonous samples.

Adsorption isotherms of TC. The data on the adsorption equilibrium of TC on the various obtained samples at room temperature are represented graphically in Figure 12.

Fig. 11. Isotherms of $\mathrm{TC}$ adsorption without (1) and (2) with chemical activation of the carbon materials (dosage $10 \mathrm{mg}$ in $20 \mathrm{~mL}$; contact time: $12 \mathrm{~h}$; temperature: $20^{\circ} \mathrm{C} ; \mathrm{pH}=7.0$; $\mathrm{C}(\mathrm{TC})$ from 200 to $400 \mathrm{mg} \cdot \mathrm{L}^{-1}$ ).

At low equilibrium concentrations $\left(1 \cdot 10^{-5} \mathrm{~mol} \cdot \mathrm{L}^{-1}\right)$, the isotherms were closely spaced for most of the adsorbents, with the activated samples showing a higher affinity to TC than the untreated samples (Fig. 11). The adsorption capacity for this equilibrium concentration range was as high as $20-850 \mathrm{mg} \cdot \mathrm{g}^{-1}$ at room 
temperature. The adsorption capacity for TC on all obtained carbonous materials increased in the following order: MC-MCM < MC-SBA < MC-SBA $\left(\mathrm{HNO}_{3}\right)<\mathrm{MC}-\mathrm{MCM}\left(\mathrm{HNO}_{3}+\mathrm{H}_{2} \mathrm{O}_{2}\right)<\mathrm{MC}-\mathrm{SBA}\left(\mathrm{H}_{2} \mathrm{O}_{2}\right)<\mathrm{MC}-$ $\mathrm{SBA}\left(\mathrm{HNO}_{3}+\mathrm{H}_{2} \mathrm{O}_{2}\right)$. The commercial activated carbons shown a lower TC adsorption capacity $\left(471 \mathrm{mg} \cdot \mathrm{g}^{-1}\right)$ than our activated materials.

In addition to the complexation mechanism of adsorption discussed above, the second kind of interactions governing the adsorption process are dispersive forces between the $\pi$ - $\pi^{*}$ electrons in the graphene layers of the carbon and the TC aromatic rings. The capacity of carbons to adsorb TC depends on the density of the delocalized $\pi$ electrons. The electron density of the carbon planes increases with the increasing content in oxygen-containing groups. In all probability, introducing oxygen-containing groups may facilitate specific oxygen interactions. An increase in acidic sites also disturbs the charge distribution of the carbon surface and creates strain that could become a new active site for adsorption of sulfur compounds. As stated above, pore accessibility is determined by the size of the pores, which should be notably larger than those of the TC molecules. The mesopore contributions and the average pore diameter of the activated carbon are near $90 \%$ and $>4 \mathrm{~nm}$, respectively (Table 1). The molecular size of TC is $0.475 \mathrm{~nm}(\mathrm{Li} \mathrm{2011)}$, but may vary due to interactions with surrounding ions. The oxygen-containing groups increase the hydrophilicity of the carbon pores and hence further enhance their accessibility to the TC molecules. These data clearly demonstrate that TC very easily enters the pores of the activated carbon. Thus, the carbon samples with the largest porosity show the highest adsorption capacity.

The equilibrium data were fitted by Langmuir and Freundlich isotherm equations (Vermeulan 1966). The Langmuir equation can be expressed as:

$$
\frac{C_{e}}{q_{e}}=\frac{1}{q_{m}} C_{e}+\frac{1}{q_{m} K_{L}}
$$

where $\mathrm{q}_{\mathrm{e}}$ is the equilibrium adsorption capacity of TC $\left(\mathrm{mg} \cdot \mathrm{g}^{-1}\right), \mathrm{C}_{\mathrm{e}}$ is the equilibrium concentration of TC in the solution $\left(\mathrm{mg} \cdot \mathrm{L}^{-1}\right), \mathrm{q}_{\mathrm{m}}$ is the maximum capacity of adsorbent $\left(\mathrm{mg} \cdot \mathrm{g}^{-1}\right)$, and $\mathrm{K}_{\mathrm{L}}$ is the Langmuir adsorption constant $\left(\mathrm{L} \cdot \mathrm{mg}^{-1}\right)$. The Freundlich isotherm equation is expressed as follow:

$$
q_{e}=K_{F} C_{e^{\frac{1}{n}}}
$$

where $K_{F}$ and $n$ are empirical constants dependent on the nature of adsorbent, solute, and the temperature, and $n$ is called the heterogeneity factor. The linear form of the equation is obtained by taking the logarithm of both sides of the equation:

$$
\ln q_{e}=\frac{1}{n} \ln C_{e}+\ln K_{F}
$$

The values of $\mathrm{q}_{\mathrm{m}}$ and $\mathrm{K}_{\mathrm{L}}$ were determined from the slope and intercept of the linear plots of $\mathrm{C}_{\mathrm{e}} / \mathrm{q}_{\mathrm{e}}$ versus $C_{e}$ (Online Resource (Fig. S4)), while the values of $\mathrm{K}_{\mathrm{F}}$ and $1 / \mathrm{n}$ were determined from the slope and intercept of the linear plot of $\ln q_{e}$ versus $\ln C_{e}$ (Table 4).

Table 4. Summary of the equilibrium isotherm parameters of various mesoporous samples.

\begin{tabular}{ccccccc}
\hline Model & Parameter & $\begin{array}{c}\text { MC-SBA } \\
\left(\mathrm{HNO}_{3}\right)\end{array}$ & MC-MCM & MC-SBA & $\begin{array}{c}\text { MC-SBA } \\
\left(\mathrm{H}_{2} \mathrm{O}_{2}\right)\end{array}$ & $\begin{array}{c}\text { MC-SBA } \\
\left(\mathrm{H}_{2} \mathrm{O}_{2}+\mathrm{HNO}_{3}\right)\end{array}$ \\
\hline \multirow{3}{*}{ Langmuir } & $\mathrm{K}_{\mathrm{L}}(\mathrm{L} / \mu \mathrm{g})$ & 377.78 & 2.15 & 243.33 & 150.00 & 157.14 \\
\cline { 2 - 7 } & $\mathrm{q}_{\mathrm{m}}(\mathrm{mg} / \mathrm{g})$ & 294.12 & 232.56 & 136.99 & 833.33 & 909.09 \\
\cline { 2 - 7 } Freundlich & $\mathrm{R}^{2}$ & 0.9994 & 0.9398 & 0.9975 & 0.9998 & 0.9990 \\
\cline { 2 - 7 } & $\mathrm{K}_{\mathrm{F}}(\mathrm{mg} / \mathrm{g})$ & 1288.84 & 76267.33 & 371.30 & 1829.50 & 1753.73 \\
\cline { 2 - 7 } & $1 / \mathrm{n}$ & 0.1671 & 0.8473 & 0.1263 & 0.0978 & 0.0808 \\
\hline & $\mathrm{R}^{2}$ & 0.8745 & 0.9857 & 0.9660 & 0.5903 & 0.7522 \\
\hline
\end{tabular}

$K_{F}$ is the Freundlich constant related to sorption capacity. The heterogeneity factor, $1 / \mathrm{n}$, is the Freundlich constant related to sorption intensity. A value of less than 1 shows stronger adsorption, though here it indicates greater heterogeneity, as the values $(\approx 0.1)$ are closer to zero, except for the MC-MCM sample. The parameters of the Freundlich model were too low to be considered reasonable, indicating that it does not represent these equilibrium data. The inapplicability of the Freundlich isotherm indicates that the adsorption is based on surface interaction rather than on surface partitioning. The determination coefficient of Langmuir's model, $\mathrm{R}^{2}(>0.93)$, is much higher than the $\mathrm{R}^{2}$ of Freundlich's model at room temperature, 
indicating that the Langmuir equation could provide a better fit for the experimental adsorption data (Fig. 11, Table 4). Based on the Langmuir isotherm, the maximal absorption capacity is equal to $909.09 \mathrm{mg} \cdot \mathrm{g}^{-1}$, obtained by the MC-SBA $\left(\mathrm{H}_{2} \mathrm{O}_{2}+\mathrm{HNO}_{3}\right)$ adsorbent at room temperature. Furthermore, the values of $\mathrm{q}_{\mathrm{m}}$ indicate a favorable adsorption of TC by the MC-SBA $\left(\mathrm{H}_{2} \mathrm{O}_{2}+\mathrm{HNO}_{3}\right)$ adsorbent.

Fig. 12. Adsorption properties of $\mathrm{MC}-\mathrm{SBA}\left(\mathrm{H}_{2} \mathrm{O}_{2}+\mathrm{HNO}_{3}\right)$ toward the family of tetracycline antibiotics in the experiment comprising six consecutive cycles of the regeneration $(\mathrm{pH}=6.0)$ - desorption $\left(0.1 \mathrm{~mol} \cdot \mathrm{L}^{-1} \mathrm{HNO}_{3}\right.$ in the first four cycles, and $1.0 \mathrm{M} \mathrm{HNO}_{3}$ in the final cycle) under dispersive solid phase extraction conditions.

Chlortetracycline, oxytetracycline, and doxycycline were also studied in the adsorption experiments (Fig. 12). The activated mesoporous carbonous samples have different adsorption capacities for this family of tetracycline antibiotics. The order of maximum adsorption capacities obtained under the same experimental conditions is: $q_{e}^{O T C} \approx q_{e}^{T C}>q_{e}^{D C}>q_{e}^{C T C}$. The sequence could not be explained considering only the different $\mathrm{pK}_{\mathrm{a}}$ values. The $\mathrm{pK}_{\mathrm{j}}$ values of tetracycline and oxytetracycline are the same $\left(p K_{a}^{T C}=p K_{a}^{O T C}=\right.$ 3.3), while the $\mathrm{pK}_{\mathrm{a}}$ value of doxycycline is the highest $\left(p K_{a}^{D C}=3.5\right)$. Furthermore, the hydrophilicity of doxycycline is lower than that of tetracycline or oxytetracycline, which facilitates adsorption onto the surface of the activated carbon with the highest amount of available O-containing groups in the mesopores. As a result, the activated carbonous suspensions have higher adsorption capacities towards oxytetracycline and tetracycline than doxycycline. As discussed above, the adsorption capacities are partly determined by the sizes of the adsorbent pores, which should be notably larger than the adsorbate molecules to ensure optimal accessibility to the pore surface (Table 1). Thus, chlortetracycline antibiotics, which have the largest moleculer size, show the lowest adsorption capacity.

The obtained MC-SBA $\left(\mathrm{H}_{2} \mathrm{O}_{2}+\mathrm{HNO}_{3}\right)$ sample demonstrates very good stability in acid and basic media, as well as complete reversibility in the process of adsorption/desorption of pharmaceuticals. It was likewise experimentally proved that complete desorption of pharmaceuticals takes place under treatment of a TC-containing adsorbent with $0.1 \mathrm{~mol} \mathrm{~L}^{-1} \mathrm{HNO}_{3}$ (Fig. 12).

The results indicate that the carbon solids obtained from the SBA-15 can be applied for trace and rapid antibiotic determination. The mesoporous activated carbon exhibits a much higher adsorptive activity and shows relatively high adsorption stability even after five cycles of adsorption-regeneration, which is potentially suitable for high efficiency and low-cost water purification.

Table 5. Comparison of the proposed technique with other approaches for the determination of pharmaceuticals.

\begin{tabular}{|c|c|c|c|c|}
\hline $\begin{array}{l}\text { Carbonous } \\
\text { material }\end{array}$ & $\begin{array}{l}\text { Synthesis conditions } \\
\text { (template, temperature } \\
\text { and etc.) }\end{array}$ & 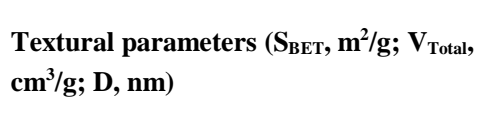 & $\begin{array}{l}\text { Adsorption performance (capacity, } \\
\text { condition, analyte, eluent, } \\
\text { regeneration) }\end{array}$ & Reference \\
\hline MC-0 & SBA-15, sucrose $+\mathrm{HNO}_{3}$ & $\begin{array}{l}\text { Weight loss (TG) }=9.4 \mathrm{wt} \%, 960 \mathrm{~m}^{2} / \mathrm{g}, \\
0.938 \mathrm{~cm}^{3} / \mathrm{g}, 3.9 \mathrm{~nm}\end{array}$ & N.D. & $\begin{array}{l}\text { Wang Da-wei, } \\
2007\end{array}$ \\
\hline MC-50 & $\begin{array}{l}\text { SBA- } 15, \text { sucrose }+\mathrm{HNO}_{3} \\
\left(50{ }^{\circ} \mathrm{C}\right)\end{array}$ & $\begin{array}{l}\text { Weight loss }(\mathrm{TG})=21.1 \mathrm{wt} \%, 710 \mathrm{~m}^{2} / \mathrm{g} \\
0.642 \mathrm{~cm}^{3} / \mathrm{g}, 3.6 \mathrm{~nm}\end{array}$ & N.D. & $\begin{array}{l}\text { Wang Da-wei, } \\
2007\end{array}$ \\
\hline MC-100 & $\begin{array}{l}\text { SBA- } 15, \text { sucrose }+\mathrm{HNO}_{3} \\
\left(100^{\circ} \mathrm{C}\right)\end{array}$ & $\begin{array}{l}\text { Weight loss (TG) }=33.9 \text { wt. } \%, 630 \mathrm{~m}^{2} / \mathrm{g} \\
0.364 \mathrm{~cm}^{3} / \mathrm{g}, 2.3 \mathrm{mn}\end{array}$ & N.D. & $\begin{array}{l}\text { Wang Da-wei, } \\
2007\end{array}$ \\
\hline R-CMC-41 & $\begin{array}{l}\text { MCM-48, rice husk, } \\
\text { hexadecyltrimethyl } \\
\text { ammonium bromide }\end{array}$ & $602 \mathrm{~m}^{2} / \mathrm{g}, 0.490 \mathrm{~cm}^{3} / \mathrm{g}, 243 \mathrm{~nm}$ & N.D. & $\begin{array}{l}\text { Boonpoke, } \\
2015\end{array}$ \\
\hline OMC-2 & $\begin{array}{l}\text { SBA-15, acrylamide, } 2- \\
\text { azobisiobutyronitrile }+\mathrm{n}, \\
\text { n-methylenebisacrylamide }\end{array}$ & $\begin{array}{l}\text { Hexagonal structure, } \mathrm{D}=0.5 \mu \mathrm{m}, \mathrm{D} \text { pore }= \\
5 \mathrm{~nm}, 432 \mathrm{~m}^{2} / \mathrm{g}\end{array}$ & $\begin{array}{l}\text { Analite: Phenolic compound, } \mathrm{qe}=37 \\
\mathrm{mg} / \mathrm{g}\end{array}$ & Shou, 2014 \\
\hline OMC-90 & $\begin{array}{l}\text { SBA-15, acrylic acid, 2.2- } \\
\text { azobisisobutyronitrile + } \\
\mathrm{HNO}_{3}\end{array}$ & $\begin{array}{l}\text { Well-ordered hexagonal arrays of } 2-\mathrm{D} \\
\text { mesoporous channels, } \mathrm{D}=10 \mathrm{~nm} \text {, groups: } \\
\text { carboxylic, lactones, ketene, }-\mathrm{NO}_{2}, 469 \\
\mathrm{~m}^{2} / \mathrm{g}\end{array}$ & $\begin{array}{l}\text { Analite: Resorcinol, } \mathrm{pH}=7, \mathrm{qe}= \\
36.3 \mathrm{mg} / \mathrm{g}\end{array}$ & Ruixuan, 2013 \\
\hline
\end{tabular}




\begin{tabular}{|c|c|c|c|c|}
\hline СМК-3 & $\begin{array}{l}\text { SBA-15, sucrose, sulfuric } \\
\text { acid }\end{array}$ & $\begin{array}{l}\text { Hexagonal symmetry, } 901.2 \mathrm{~m}^{2} / \mathrm{g}, 0.97 \\
\mathrm{~cm}^{3} / \mathrm{g}, 4.3 \mathrm{~nm}\end{array}$ & $\begin{array}{l}\text { Analite: } \mathrm{DY}-12, \mathrm{qe}=370.4 \mathrm{mg} / \mathrm{g}, \mathrm{T}= \\
318.15 \mathrm{~K}\end{array}$ & Fengling, 2009 \\
\hline CMK-3-s & $\begin{array}{l}\text { SBA-15, sucrose, sulfuric } \\
\text { acid }\end{array}$ & $\begin{array}{l}\text { Hexagonal structure, } 1120 \mathrm{~m}^{2} / \mathrm{g}, 1.22 \\
\mathrm{~cm}^{3} / \mathrm{g}, 3.6 \mathrm{~nm}\end{array}$ & N.D. & Lysenko, 2011 \\
\hline O-CMK-3 & $\begin{array}{l}\text { CMK-3 (SBA-15, sucrose, } \\
\text { sulfuric acid), ammonium } \\
\text { persulfate }+\mathrm{H}_{2} \mathrm{SO}_{4}\end{array}$ & $\begin{array}{l}\text { Rope-like structure, groups: carbonyl, } \\
\text { carboxyl, } 999.9 \mathrm{~m}^{2} / \mathrm{g}, 0.96 \mathrm{~cm}^{3} / \mathrm{g}, 3.75 \mathrm{~nm}\end{array}$ & $\begin{array}{l}\text { Analite: N-nitrosamines, LOQs } \geq \\
0.005 \mathrm{ng} / \mathrm{L}, \text { Desorption: } \\
\text { dichloromethane, } \mathrm{t}=15 \mathrm{~min}\end{array}$ & Lashgari, 2017 \\
\hline CMK-3 & SBA-15, sucrose, $\mathrm{H}_{2} \mathrm{SO}_{4}$ & $\begin{array}{l}\text { Ordered hexagonal arrays of mesopores } \\
\text { structure, have phenolic, groups: lactonic, } \\
\text { carbonyl, carboxylic, } 940.8 \mathrm{~m}^{2} / \mathrm{g}, 0.796 \\
\mathrm{~cm}^{3} / \mathrm{g}, 3.65 \mathrm{~nm}\end{array}$ & $\begin{array}{l}\text { Analit: Diazonin, } \mathrm{pH}=4-6,25 \mathrm{~mL} \\
(100 \mathrm{ng} / \mathrm{L}) \text {, Sorbent: } 25 \mathrm{mg}, \mathrm{R}= \\
95.80-104.94 \%\end{array}$ & Beirami, 2016 \\
\hline $\begin{array}{l}\mathrm{Au} @ \mathrm{CMK}- \\
3-\mathrm{O}\end{array}$ & $\mathrm{CMK}-3+\mathrm{Au}$ & $\begin{array}{l}\mathrm{D}=10 \mathrm{~nm}, \text { rod-like shape, groups: } \\
\text { carbonyl, carboxyl, } 984.6 \mathrm{~m}^{2} / \mathrm{g}, 1.19 \\
\mathrm{~cm}^{3} / \mathrm{g}, 4.25 \mathrm{~nm}\end{array}$ & $\begin{array}{l}\text { Analite: P-nitrophenol, } \mathrm{pH}=10.15 \text {, } \\
\text { Extractant: } \mathrm{CH}_{2} \mathrm{CI}_{2}, \text { Sorbent: } 75 \mathrm{mg}, \\
\mathrm{R}=87 \%(\mathrm{t}=5 \mathrm{~min})\end{array}$ & Lin Tang, 2016 \\
\hline $0.2 \mathrm{AO}-\mathrm{OMC}$ & $\begin{array}{l}\text { CMK-3, 2-butenenitrile, } \\
\text { dichloromethane, } \\
\text { polyacrylamide }+ \\
\text { hydroxylamine } \\
\text { hydrochloride solution }\end{array}$ & $\begin{array}{l}\text { Aggregated rod-like particles, ordered } \\
\text { mesopore channels, } D=8 \mathrm{~nm} \text {, hexagonal } \\
\text { symmetry, amidoxime groups, } 865.9 \mathrm{~m}^{2} / \mathrm{g}\end{array}$ & $\begin{array}{l}\text { Analite: } \mathrm{U}(\mathrm{VI}), \mathrm{pH}=4.24, \mathrm{q}_{\mathrm{e}}=322.6 \\
\mathrm{mg} / \mathrm{g}(\mathrm{t}=1 \mathrm{~h}), \mathrm{pseudo}-\mathrm{second}-\text { order } \\
\text { kinetic, Desorbents: HCI }(1.0-2.0 \\
\mathrm{mol} / \mathrm{L})\end{array}$ & Zhang, 2018 \\
\hline CMK-3-NH3 & $\begin{array}{l}\text { SBA-15, sucrose, } \mathrm{H}_{2} \mathrm{SO}_{4}+ \\
\mathrm{NH}_{3}\end{array}$ & $\begin{array}{l}\text { 2D-hexagonal structure, amine groups, } \\
1633 \mathrm{~m}^{2} / \mathrm{g}, 1.55 \mathrm{~cm}^{3} / \mathrm{g}, 3.1 \mathrm{~nm}\end{array}$ & $\begin{array}{l}\text { Analite: Formaldehyde, } \mathrm{C}=100 \mathrm{ppm}, \\
\mathrm{V}=10 \mathrm{~L}, \mathrm{t}=10 \mathrm{~min}, \mathrm{~m}=0.07 \mathrm{~g}, \mathrm{R}> \\
50 \%\end{array}$ & Bum An, 2012 \\
\hline CMK-3 & $\begin{array}{l}\text { SBA-15, furfuryl alcohol, } \\
\text { toluene, } \mathrm{H}_{2} \mathrm{SO}_{4}\end{array}$ & $\begin{array}{l}\text { 2D hexagonal symmetry, } 1420 \mathrm{~m}^{2} / \mathrm{g}, 1.14 \\
\mathrm{~cm}^{3} / \mathrm{g}, 4.0 \mathrm{~nm}\end{array}$ & $\begin{array}{l}\text { Analite: Bisphenol A, } \mathrm{q}_{\mathrm{e}}=474 \mathrm{mg} / \mathrm{g}, \\
\mathrm{t}=20 \mathrm{~min}\end{array}$ & Libbrecht, 2015 \\
\hline CMK-3 & SBA-15, sucrose, $\mathrm{H}_{2} \mathrm{SO}_{4}$ & $\begin{array}{l}\text { Hexagonal structure, rod-like morphology, } \\
1113.7 \mathrm{~m}^{2} / \mathrm{g}, 1.19 \mathrm{~cm}^{3} / \mathrm{g}, 4.21 \mathrm{~nm}\end{array}$ & $\begin{array}{l}\text { Analite: 4-chlorophenol, } \mathrm{pH}=5-7,3 \\
\text { regeneration-reuse cycles. } \mathrm{q}_{\mathrm{e}}=333.3 \\
\mathrm{mg} / \mathrm{g}\end{array}$ & $\begin{array}{l}\text { Madannejad, } \\
2018\end{array}$ \\
\hline $\begin{array}{l}\text { Comercial } \\
\text { CAS: } 7440- \\
44-0\end{array}$ & & $\begin{array}{l}\text { Apparent density }=290 \mathrm{~kg} / \mathrm{m}^{3}, 875 \mathrm{~m}^{2} / \mathrm{g} \text {, } \\
1.2 \mathrm{~nm}\end{array}$ & Large range of water applications & $\begin{array}{l}\text { Norit } \\
\text { digitallibrary, } \\
\text { Fluka }\end{array}$ \\
\hline MC-SBA & $\begin{array}{l}\text { SBA-15, polystyrene, } \\
\text { sucrose, } \mathrm{H}_{2} \mathrm{SO}_{4}, \\
\text { Activation: } \mathrm{H}_{2} \mathrm{O}_{2}+\mathrm{HNO}_{3}\end{array}$ & $\begin{array}{l}\text { Hexagonal structure, } 2340 \mathrm{~m}^{2} / \mathrm{g}, 2.51 \\
\mathrm{~cm}^{3} / \mathrm{g}, 6.61 \mathrm{~nm}\end{array}$ & $\begin{array}{l}\text { Analite: Tetracycline, } \mathrm{pH}=5-7, \mathrm{q}_{\mathrm{e}}= \\
345.2 \mathrm{mg} / \mathrm{g}\end{array}$ & This work \\
\hline
\end{tabular}

Table 5 shows that the adsorption performance of the proposed adsorbent based on mesoporous chemically activated carbon materials for pharmaceuticals removal is high/better than that of most analogical adsorbents. These results suggest that the mesoporous activated carbon materials thus produced constitute excellent candidates for ultrasensitive and rapid uptake of pharmaceuticals.

\section{Conclusions}

Mesoporous carbon materials based on ordered mesoporous silica were synthesized and activated. The morphological and physico-chemical characteristics were determined. The relationship between textural properties and surface chemistry vs adsorption behavior of the mesoporous carbon materials was demonstrated. Tetracycline antibiotics were used as the model analytes. Pseudo-second-order models describe the adsorption kinetics of tetracycline on carbon solids in the best way, while Langmuir's model provides a good fit for the adsorption isotherms. The mechanism of adsorption of TC by the carbon material was proposed. The relationship between the adsorption behavior and the surface acid-base properties of the carbonous adsorbents was also studied. The adsorption capacity is enhanced after the chemical activation of the materials. These carbon adsorbents may potentially find an application in the removal of different organic compounds from municipal wastewater and natural waters. 
Acknowledgements. This study was supported by grants from EU FP-7-PEOPLE-2009-IRSES (№ 247603). The University of Oviedo is grateful for financial support from Spain's Ministry for the Economy and Business - MINECO (MAT2016-78155-C2-1-R).

\section{References}

Ahmed, M.B.: Adsorptive removal of antibiotics from water and wastewater: Progress and challenges. Sci. Total Environ., 532, 112-126 (2015).

Ahmed, M.J., Hameed, B.H.: Removal of emerging pharmaceutical contaminants by adsorption in a fixed bed column: A review. Ecotoxicol Environ Saf., 149, 257-266 (2018).

Álvarez-Torrellas, S., Peres, J.A., Gil-Álvarez, V., Ovejero, G., García, J.: Effective adsorption of nonbiodegradable pharmaceuticals from hospital wastewater with different carbon materials. Chem. Eng. J., 320, 319-329 (2017).

Álvarez-Torrellas, S., Rodríguez, A., Ovejero, G., García, J.: Chemical-activated carbons from peach stones for the adsorption of emerging contaminants in aqueous solutions. Chem. Eng. J., 279, 788-798 (2015).

Ania, C.O., Pelayo, J.G., Bandosz, T.J.: Reactive adsorption of penicillin on activated carbons. Adsorption, 17, 421-429 (2011).

Andrade, J.R, Oliveira, M.F., da Silva Meuris, G.C., Vieira Melissa, G.A.: Adsorption of pharmaceuticals from water and wastewater using nonconventional low-cost materials: A review. Ind. Eng. Chem. Res., 57, 3103-3127 (2018).

Barrett, E.P., Joyner, L.G., Halenda, P.P.: The determination of pore volume and area distributions in porous substances. I. Computations from nitrogen isotherms. J. Am. Chem. Soc., 373-380 (1951).

Beirami, S., Rahimzadeh Barzoki, H., Bahramifar, N.: Application of response surface methodology for optimization of trace amount of diazinon preconcentration in natural waters and biological samples by carbon mesoporous CMK-3. Biomed. Chromatogr., 31, 3874-3886 (2017).

Boatman M.: Survey of antimicrobial usage in animal health in the European Union. Boatman consulting report for FEDESA. (1998).

Boehm H.P.: Surface oxides on carbon and their analysis: a critical assessment. Carbon 40, 145-149 (2002).

Boonpoke, A., Chiarakorn, S., Laosiripojana, N., Towprayoon S., Chidthaisong, A.: Synthesis of activated carbon and MCM-41 from bagasse and rice husk and their carbon dioxide adsorption capacity, JSEE, 2, 77-81 (2011).

Bottani, E.J., Tascón, J M.D.: Adsorption by carbons. Elseveir Science (2008).

Bum An, H., Jin Yu, M., Man Kim, J., Jin, M., Jong-Ki, J., Hoon Park, S., Kim, S., Park, Y.: Indoor formaldehyde removal over CMK-3. Nanoscale Res. Lett., 7, 7 (2012).

Charu, B., Upendra, N., Ashok, K.P., Neha, G.: Mesoporous silica nanoparticles in target drug delivery system: A review. Int. J. Pharma Investig., 5, 124-133 (2015).

Chen, S., Zhang, J., Zhang, C., Yue, Q., Li, Y., Li, C.: Equilibrium and kinetic studies of methyl orange and methyl violet adsorption on activated carbon derived from Phragmites australis. Desalination 252, 149-156 (2010).

Colombo, P., Paulson, T.E., Pantano C.G.: Synthesis of silicon carbide thin films with polycarbosilane (PCS). J. Am. Ceram. Soc., 80, 2333-40 (1997).

Da Costa Lopes, A.S., Leão de Carvalho, S.M., Barros Brasil, D.S., Rosivaldo de Alcântara M., Oliveira Lima, M.: Surface modification of commercial activated carbon (CAG) for the adsorption of benzene and toluene. AJAC, 6 , 528-538 (2015).

Da-wei, W., Feng, L., Min, L., Hui-ming, C.: Improved capacitance of SBA-15 templated mesoporous carbons after modification with nitric acid oxidation. New Carbon Mater., 22, 307-314 (2007).

Duff B.: Presence of tetracycline antibiotics in surface water a study of the presence/absence of tetracycline in the raccoon river watershed, Des Moines Water Works Laboratory. Environ. Sci. Technol., 39, 496-503 (2005).

El-Sayed, Y., Bandosz, T.J.: Adsorption of valeric acid from aqueous solution onto activated carbons: role of surface basic sites. J. Colloid Interface Sci., 273, 64-72 (2004).

Fatta-Kassinos D., Meric, S.: Pharmaceutical residues in environmental waters and wastewater: Current state of knowledge and future research. Anal. Bioanal. Chem., 399, 251- 275 (2011).

Figueiredo, J.L., Sousa, J.P.S., Orge, C.A., Pereira, M.F.R., Orfao, J.J.M.: Adsorption of dyes on carbon xerogels and templated carbons: Influence of surface chemistry. Adsorption, 17, 431-441 (2010).

Fuertes, A.B., Nevskaia, D.M.: Control of mesoporous structure of carbons synthesized using a mesostructured silica template. Micropor. Mesopor. Mater., 62, 177-190 (2003).

Guedidi, H., Reinert, L., Leveque, J.M., Soneda, Y., Bellakhal, N., Duclaux, L.: The effects of the surface oxidation of activated carbon, the solution $\mathrm{pH}$ and the temperature on adsorption of ibuprofen. Carbon, 54, 432-443 (2013).

Guo, R., Guo, L., Yu, F., Dianchen Gang D.: Synthesis and surface functional group modifications of ordered mesoporous carbons for resorcinol removal. Micropor. Mesopor. Mater., 175, 141-146 (2013). 
Guo, P., Tang, L., Tang, J., Zeng, G., Huang, B., Dong, H., Zhang, Y., Zhou, Y., Deng, Y., Shiru Tan, M.: Catalytic reduction-adsorption for removal of p-nitrophenol and its conversion p-aminophenol from water by gold nanoparticles supported on oxidized mesoporous carbon. Colloid Interface Sci., 469, 78-85 (2016).

Ho, Y.S., McKay, G.: Pseudo-second order model for sorption processes. Process Biochem., 34, 451-465 (1999).

Hong, C.-E., Lee, J.-H., Kalappa, P., Advani, S.G.: Effects of oxidative conditions on properties of multi-walled carbon nanotubes in polymer nanocomposites. Comp. Sci. Technol., 67, 1027- 1037 (2007).

Husbands, D.I., Tallis, W., Waldsax, J.C.R., Woodings, C.R., Jaycock, M.J.: A study of the adsorption of stearic acid onto ferric oxide. Powder Technol., 5, 31-38 (1971).

Ji, L., Wan, Y., Zheng, S., Zhu, D.: Adsorption of tetracycline and sulfamethoxazole on crop residue-derived ashes: Implication for the relative importance of black carbon to soil sorption. Environ. Sci. Technol., 45, 5580-5586 (2011)

Jia, Y.F., Thomas K. M.: Adsorption of cadmium ions on oxygen surface sites in activated carbon. Langmuir, $16,1114-1122$ (2000).

Kruk, M., Jaroniec, M., Ryoo, R., Joo, S.H.: Characterization of ordered mesoporous carbons synthesized using MCM-48 silicas as templates. J. Phys. Chem. B, 104, 7960-7968 (2000).

Kummerer, K.: Antibiotics in the aquatic environment. A review. Part I Chemosphere, 75, 417-434 (2009).

Lagergren, S., Svenska, B.K.: On the theory of so-called adsorption of dissolved substances. The Royal Swedish Academy of Sciences Document, Band 24, 1 (1898).

Lashgari, M., Yamini, Y., Basheer, C., Kee Lee, H.: Ordered mesoporous carbon as sorbent for the extraction of N-nitrosamines in wastewater and swimming pool water. J. Chromatogr. A, 1513, 35-41 (2017).

Lateefa, A.A., Weaam, H., Salam, M.A.: Removal of non-steroidal anti-inflammatory drugs from water using high surface area nanographene: Kinetic and thermodynamic studies. J. Mol. Liq., 241, 733-741 (2017).

Libbrecht, W., Vandaele, K., De Buysser, K., Verberckmoes, A., Thybaut, W., Poelman, H., De Clercq, J., Van Der Voort, P.: Tuning the pore geometry of ordered mesoporous carbons for enhanced adsorption of bisphenol-A. Materials, 8, 1652-1665 (2015).

Liu, F., Wang, J., Li, L., Shao, Y., Xu, Z., Zheng, S.: Adsorption of direct Yellow 12 onto ordered mesoporous carbon and activated carbon. J. Chem. Eng. Data, 54, 3043-3050 (2009).

Lysenko, N., Yaremov, P., Ilyin, V., Ovcharova, M.: Conditions and features of matrix and bulk carbonization of the organic precursors. J. Mater. Sci., 46, 4465-4470 (2011).

Madannejad, S., Rashidi, A., Sadeghhassani, S., Shemirani, F., Ghasemy, E.: Removal of 4-chlorophenol from water using different carbon nanostructures: A comparison study. J. Mol. Liq., 249, 877-885 (2018).

Martins, A.C., Junior, O.P., Cazetta, A.L., Bedin, K.C., Yamazaki, D.A.S., Bandoch, G.F.G., Asefa, T., Visentainer, J.V., Almeida, V.C.: Removal of tetracycline by $\mathrm{NaOH}$-activated carbon produced from macadamia nut shells: kinetic and equilibrium studies. Chem. Eng. J., 260, 291-299 (2015).

Martins, A.C., Pezoti, A.L., Bedin, K.C., Yamazaki, D.A.S., Bandoch, G.F., Almeida V.C.: Removal of tetracycline by $\mathrm{NaOH}$-activated carbon produced from macadamia nut shells: Kinetic and equilibrium studies. Chem. Eng. J., 260, 291-299 (2015).

Mcevoy, J.D.G.: Contamination of animal feeding stuffs as a cause of residues in food: a review of regulatory aspects, incidence and control. Review. Anal. Chim. Acta. 473, 3-26 (2002).

Mbileni, Ch.N., Prinsloo, F.F., Witcomb, M.J., Coville, N.J.: Synthesis of mesoporous carbon supports via liquid impregnation of polystyrene onto a MCM-48 silica template. Carbon, 44, 1476-1483 (2006).

Miyata, Y., Maniwa, Y., Kataura, H.: Selective oxidation of semiconducting single-wall carbon nanotubes by hydrogen peroxide. J. Phys. Chem. B, 110, 25-29 (2006).

Moral-Rodriguez, A.I., Leyva-Ramos, R., Ocampo-Perez, R., Mendoza-Barron, J., Serratos-Alvarez, I.N., Salazar-Rabago, J.J.: Removal of ronidazole and sulfamethoxazole from water solutions by adsorption on granular activated carbon: equilibrium and intraparticle diffusion mechanisms. Adsorption 22, 89-103 (2016).

Moreno-Castilla, C., Carrasco-Marin, F., Maldonado-Hodar, F.J., Rivera-Utrilla, J.: Effects of non-oxidant and oxidant acid treatments on the surface properties of an activated carbon with very low ash content. Carbon, 36,145-51 (1998).

Moussavi, G.: Preparation, characterization and adsorption potential of the $\mathrm{NH}_{4} \mathrm{Cl}$-induced activated carbon for the removal of amoxicillin antibiotic from water. Chem. Eng. J., 217, 119-128 (2013).

Muthanna, J.A., Adsorption of non-steroidal anti-inflammatory drugs from aqueous solution using activated carbons: Review. J. Envir. Mgm., 190, 274-282 (2017).

Polubesova, T., Zadaka, D., Groisman, L., Nir, S.: Water remediation by micelle-clay system: Case study for tetracycline and sulfonamide antibiotics. Water Res., 40, 2369-2374 (2006).

Pouretedal, H., Sadegh N.: Effective removal of amoxicillin, cephalexin, tetracycline and penicillin G from aqueous solutions using activated carbon nanoparticles prepared from vine wood. J. Water Process Eng., 1, 64-73 (2014).

Putra, E.K.: Performance of activated carbon and bentonite for adsorption of amoxicillin from wastewater: Mechanisms, isotherms and kinetics. Water Res., 43, 2419-2430 (2009). 
Salvia, M.V., Cren-Olivé, C., Wiest, L., Baudot, R., Vulliet, E.: Comparison of two analytical methods for the determination of traces of veterinary antibiotics and steroid hormones in soil based on pressurised liquid extraction (PLE) and quick, easy, cheap, effective, rugged, safe (modified-quechers) extraction. Pharmaceutica Analytica Acta (2014).

Shou, W., Chao, B., Gang, D.: Improving adsorption capacity of ordered mesoporous carbon (OMC) through addition of crosslink agent. NSTI-Nanotech., 3 (2014).

Thommes, M., Kaneko, K., Neimark, A.V., Olivier, J.P., Rodríguez-Reinoso, F., Rouquerol, J., Sing, K.S.W.: Physisorption of gases, with special reference to the evaluation of surface area and pore size distribution (IUPAC Technical Report). Pure Appl. Chem., 87, 1051-1069 (2015).

Telbiz, G.M., Gerda, V.I., Kobylinska, N.G., Zaitsev, V.M., Fraissard, J. Studies of Hydrogen sorption on Mesoporous Carbon composite modified with adsorbed Palladium. NATO Science for Peace and Security Series C: Environmental Security, 2, 499-508 (2011).

Ting, W., Siyu, L., Guihua, G., Pan, Z., Nan, L., Xiaowen, L., Xiaohong. H.: Magnetic solid phase extraction of non-steroidal anti-inflammatory drugs from water samples using a metal organic framework of type $\mathrm{Fe}_{3} \mathrm{O}_{4} / \mathrm{MIL}$ 101(Cr), and their quantitation by UPLC-MS/MS. Microchim. Acta, 184, 2981-2990 (2017).

Vermeulan, T.H., Vermeulan, K.R., Hall, L.C.: Fundamental. Ind. Eng. Chem., 5, 212-223 (1966).

Xia, Y., Mokaya, R.: Synthesis of ordered mesoporous carbon and nitrogen-doped carbon materials with graphitic pore walls via a simple chemical vapor deposition method. Adv Mater., 16, 1553-1558 (2004).

Zaitsev, V.N., Kobylinskaya, N.G., Kostenko, L.S., Gerda, V.I.: Conductometric determination of the concentration of acid centers on functionalized materials. J. Anal. Chem., 63, 779-786 (2018).

Zhao, Y., Feng, J., Huo, Q., Melosh, N., Fredrickson, G.H., Chmelka, B.F., Stucky, G.D.: Triblock copolymer syntheses of mesoporous silica with periodic 50 to 300 angstrom pores. Science, 279, 548-553 (1998).

Zhao, Y., Tong, E., Gu, X., Gu, C., Wang, X., Zhang, Y. Insights into tetracycline adsorption onto goethite: Experiments and modeling. Sci. Total Environ., 19, 470-471 (2014).

Zhanga, Z., Donga, Z., Wang, X., Yinga, D., Niuc, F., Caoa, X,. Wanga, Y., Huaa, R., Liua, Y., Wang, X.: Ordered mesoporous polymer-carbon composites containing amidoxime groups for uranium removal from aqueous solutions. Chem. Eng. Sci., 341, 208-217 (2018).

Zhou, A.N., Ma, X.L., Song, C.S., Liquid-phase adsorption of multi-ring thiophenic sulfur compounds on carbon materials with different surface properties. J. Phys. Chem. B, 110, 4699-707 (2006). 